\title{
Little Things Mean a Lot
}

\author{
Steven N. Handel
}

"If human beings were not so impressed by size alone, they would consider an ant more wonderful than a rhinoceros." (Wilson 1987 , p. 345)

$\mathrm{B}$ igger is better we are told since childhood, and our human experiences, from bank accounts to professional sport team preferences, support this world view. Or should we say canard?

Successful ecological restoration depends on many small species, not just the elegant plants and charming animals that consume so much of our time and the public's interest. The functioning of ecological communities involves thousands of invertebrates and their many roles.

For example, beneficial insects control ecological processes in many ways. Some are mutualists, such as pollinators and seed dispersers, that facilitate plant reproduction and spread (Howe and Westley 1988). Others populate the food web and are required for vertebrate community health (e.g., Askins 2000). Others, the herbivores and consumers, are necessary to regulate plant community structure and successional dynamics (Perrow and Davy 2002, Temperton et al. 2004).

Sometimes even small, uncommon invertebrate species are critical to landscape health. The biological control of St. Johnswort (Hypericum perforatum) by the Klamath weed beetle (Chrysolina quadrigemina) is a famous example (Holloway and Huffaker 1951). This non-native plant swept through the grasslands of central California, ruining thousands of hectares of economically valuable land. The release of the plant's biocontrol agent, the beetles, pushed back the plant invader. The weed still persists in small patches in the shade where the beetle prefers not to oviposit and produces some seeds. New St. Johnswort plants that colonize the open pasture are eventually found by the beetle and eaten. Today the beetle and weed numbers are very small, but without that beetle, the pastures would again be overrun by the noxious plant. A similar example is known from Australia, where prickly pear cactus (Opuntia stricta) swept through the country until it was parried by the herbivory of one dull moth species. Some cactus moths (Cactoblastis cactorum) still patrol the outback, but being uncommon is not the same as being unimportant.

Ecological Restoration Vol. 30, No. 3, 2012

ISSN 1522-4740 E-ISSN 1543-4079

C 2012 by the Board of Regents of the University of Wisconsin System.
For many of these invertebrate groups, microhabitat complexity must be established. Sometimes a host plant is needed for specialist insects. Sometimes the need is fallen wood of various diameters; dead plants can be as critical to restoration success as healthy stock from commercial nurseries. Many vertebrates also require dead wood for their needs from thermoregulation to oviposition. We must lose our large-scale perspective and incorporate very small-scale features into design and installation activities (Wiens and Milne 1989, Packard and Mutel 1997, Stoner and Joern 2004, Jonsson et al. 2005).

Some workers assume that once plant communities are installed, a complete community of insects and other invertebrates will soon follow. We have little data for many habitats to predict the dynamics of insect and other arthropod dispersal. Some studies frighten us. Reed (1995) showed that among 4 restored prairie remnants in Minnesota, the pollinator community varied enormously and never matched the diversity on natural prairie remnants. Simberloff's well-cited studies (e.g., Simberloff and Abele 1976) on island biogeography also show that insect assemblages on vegetation treated to eliminate the original insects may not reiterate the original community. Build it, and they will come? If only this were true.

For successful restoration ecology practice, we must champion even the smallest sized species to anchor success. Management guides are available (Kirby 2001, Mader et al. 2011). During the design phase, the usual suspects must be addressed: Do we have the proper staff specialists to ensure that full biodiversity is being considered? Have we surveyed and characterized the adjacent areas to understand the probability that migration of small species is probable? Have we addressed an adequate biodiversity of installed plants to accommodate the life history needs of common and preferred insects? Have we included microsite features such as fallen wood and cobbles, as peculiar as they can be when added to a blueprint, to facilitate life history success? Do monitoring instructions include invertebrate biodiversity as well as the number of live stems? Have we educated the public and the regulators that rich invertebrate biodiversity is critical for ecological restoration health?

The pop song that motivated our title includes the line, "Say I look nice when I'm not." That pasture or woodland, after restoration, may look lush and green, but its longterm fate will be challenged without the species that are 
obscure or even disliked. We must lose our conceit that big and familiar species alone define our work, and turn our eyes down to the small players on the ecological stage. The charismatic megafauna share the stage with the obscure microfauna.

\section{References}

Askins, R.A. 2000. Restoring North America's Birds: Lessons from Landscape Ecology. New Haven, CT: Yale University Press.

Howe, H.F. and L.C. Westley. 1988. Ecological Relationships of Plants and Animals. New York, NY: Oxford University Press.

Holloway, J.K. and C.B. Huffaker. 1951. The role of Chrysolina quadrigemina in the biological control of Klamath weed. Journal of Economic Entomology 44:244-247.

Jonsson, B.G., N. Kruys and T. Ranius. 2005. Ecology of species living on dead wood-Lessons for dead wood management. Silva Fennica 39:289-309.

Kirby, P. 2001. Habitat Management for Invertebrates: A Practical Handbook. Sandy Bedfordshire, UK: Royal Society for the Protection of Birds.

Mader, E., S. Shepherd, M. Vaughn, S.H. Black and G. LeBuhn. 2011. Attracting Native Pollinators: Protecting North America's Bees and Butterflies. North Adams, MA: Storey Publishing.
Packard, S. and C.F. Mutel (eds). 1997. The Tallgrass Restoration Handbook for Prairies, Savannas, and Woodlands. Washington, DC: Island Press.

Perrow, M.R. and A.J. Davy (eds). 2002. Handbook of Ecological Restoration, Volume 1, Principles of Restoration. Cambridge, UK: Cambridge University Press.

Reed, C.C. 1995. Insects surveyed on flowers in native and reconstructed prairies (Minnesota). Restoration and Management Notes 13:210-213.

Simberloff, D. and L.G. Abele. 1976. Island biogeography theory and conservation practice. Science 191:285-286.

Stoner, K.J.L. and A. Joern. 2004. Landscape vs. local habitat scale influences to insect communities from tallgrass prairie remnants. Ecological Applications 14:1306-1320.

Temperton, V.M., R.J. Hobbs, T. Nuttle and S. Halle. 2004. Assembly Rules and Restoration Ecology: Bridging the Gap Between Theory and Practice. Washington, DC: Island Press.

Weins, J.A. and B.T. Milne. 1989. Scaling of 'landscapes' in landscape ecology, or, landscape ecology form a beetle's perspective. Landscape Ecology 3:878-896.

Wilson, E.O. 1987. The little things that run the world (The importance and conservation of invertebrates). Conservation Biology 1:344-346. 